(CLAF), International Center for Diffraction Data (ICDD), Bruker AXS, Rigaku Corp., and Panalytical.

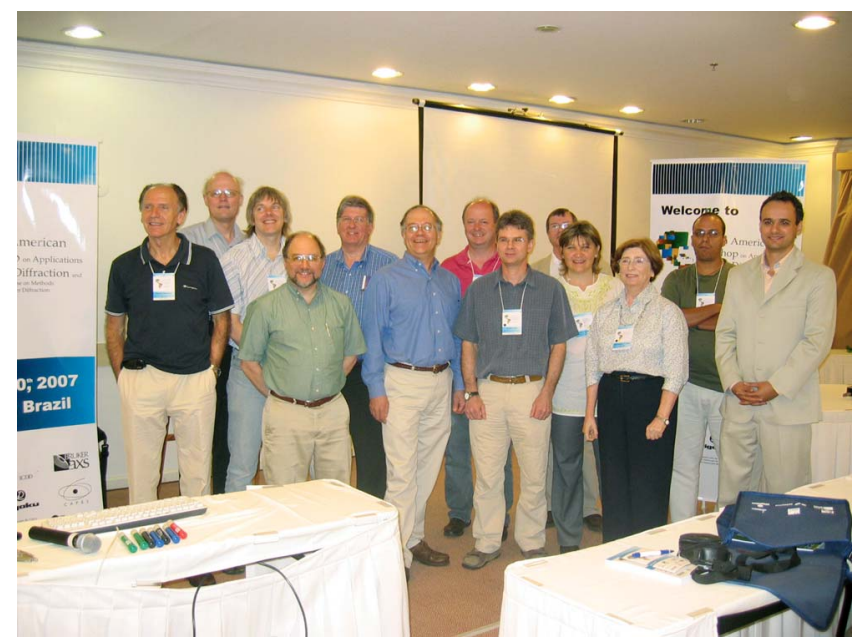

Lecturers and some of the organizers for 2007 LAWPD (from left to right): C. Giacovazzo, J. Kaduk, S. Billinge, Brian Toby, Bob von Dreele, Bill David, Andy Fitch, Armel Le Bail, Silvia Cuffini, Iris Torriani, Ernesto Estevez-Rams, and Eduardo Granado

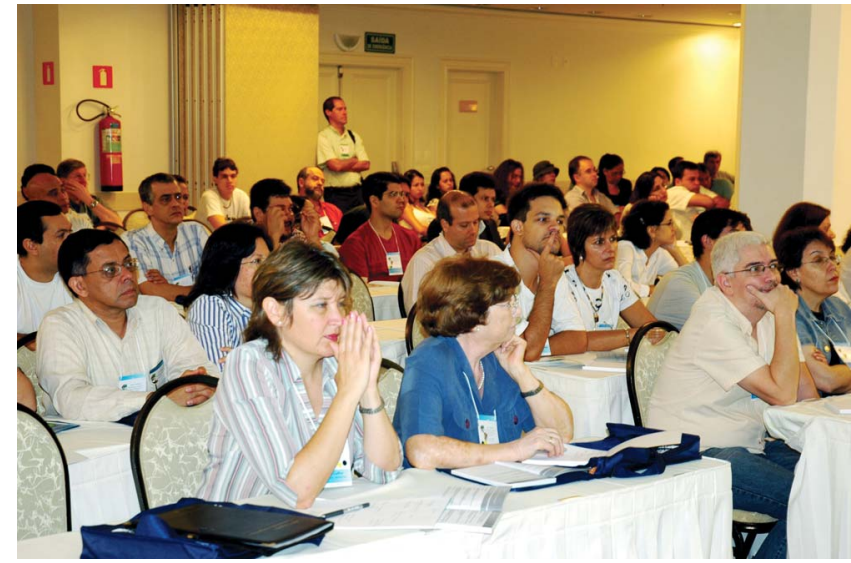

Scene from a LAWPD lecture

A touch of originality was given by a soccer match organized during the day of visit to the Synchrotron Lab, between the "locals" and the "visitors." Although there was not total agreement as to who the winner of this match was, the crystallographic community had no doubt that they were all winners in this single event.

\title{
Calendar of Meetings
}

\author{
Donald R. Petersen \\ Greenleaf Associates, \\ 6210 Siebert Street \\ Midland, MI 48640-2724, USA \\ drpetersen@ royager.net
}

\section{9-14 September 2007}

EuroAnalysis XIV. Antwerp, Belgium. [Contact: Luc Van't Dack, Department of Chemistry, University of Antwerp, Universiteitsplein 1, B-2610 Antwerp, Belgium. Tel: 32 (3) 820 23 43; Fax: 32 (3) 82023 43; E-mail: Luc.Vantdack@ ua.ac.be; Info: http://www.euroanalysisxiv.ua.ac.be].

\section{9-14 September 2007}

23rd International Meeting on Organic Geochemistry. Torquay, England, UK. [Contact: Hannah Evans, IMOG 2007 Secretariat, IGI Ltd., Hallsannery, Bideford, Devon EX39 5HE, UK. Tel: 44 (1237) 471 749; Fax: 44 (1237) 421 700; E-mail: secretary@imog2007.org; Info: http:// www.imog2007.org/index.htm].

\section{2-13 September 2007}

Annual Meeting of the Swiss Society of Crystallography. Villigen, Switzerland. Held at the Paul Scherrer Institut in conjunction with the Eighth SLS Users' Meeting (11-12 September) and featuring a Workshop on Cement Research at Large-scale Facilities (10 September). [Info: http://diffraction.web.psi.ch/sgk-sscr-2007.htm].

\section{7-21 September 2007}

E-MRS Fall Meeting: Symposium I. Warsaw, Poland. "New Opportunities and Challenges in Materials Research using Synchrotron and Free Electron Laser Sources." [Contact: Agnieszka Rytel, Conference Secretariat, Faculty of
Materials Science and Engineering, 141 Waloska Street, 02507 Warsaw, Poland. Tel/Fax: 48 (22) 2348794; E-mail: warsaw.fall@e-mrs.org; Info: http://www.e-mrs.org/ meetings/fall2007/I.html].

\section{7-21 September 2007}

Joint 21st AIRAPT and 45th EHPRG International Conference on High Pressure Science and Technology. Catania, Sicily, Italy. Held at the University of Catania. [Contact: G. G. N. Angilella, Department of Physics and Astronomy, University of Catania, Via S. Sofia 64, Catania I-95123, Italy. Fax: 39 (095) 378 5231; E-mail: info@ airapt-ehprg-2007.it; Info: http://www.aip.org/cal/viewbyuser.jsp?eid=1084].

\section{7-9 October 2007}

5th Size-Strain Conference: Diffraction Analysis of the Microstructure of Materials. Garmisch-Partenkirchen, Germany. [Info: http://www.mf.mpg.de/en/abteilungen/ mittemeijer/ss-v/welcome.htm].

\section{2-18 October 2007}

34th Annual Conference of the Federation of Analytical Chemistry and Spectroscopy Societies (FACSS). Memphis, Tennessee, USA. [Contact: Cindy Lilly, FACSS, Post Office Box 24379, Santa Fe, NM 87502, USA. Tel: 1 (505) 820 1648; Fax: 1 (505) 989 1073; E-mail: fascc@facss.org; Info: http://www.facss.org]. 
4-7 November 2007

Eighth Conference of the Asian Crystallographic Association. Taipei, Taiwan, R. O. C. [Contact: AsCA 2007 Secretariat, Tze-Chiang Foundation of Science and Technology, 101 Sect. 2 Kuang Fu Road, Hsinchu 30013, Taiwan. Tel: 886 (3) 5726360; Fax: 886 (3) 5716782; E-mail: asca2007@tcfst.org.tw; Info: http://www.asca2007.tw/ index.html].

\section{November 2007}

British Crystallographic Association Pharmaceutical Special Interest Group. Macclesfield, Cheshire, England, UK. [Info: http://img.cryst.bbk.ac.uk/BCA/ig/meet07AM. htm].

\section{November 2007}

British Crystallographic Association Annual Meeting. Macclesfield, Cheshire, England, UK. [Info: http:// img.cryst.bbk.ac.uk/BCA/ig/meet07AM.htm].

\section{2-8 February 2008}

AXAA 2008 Schools, Advanced Workshops, Conference \& Exhibition. The Grand Hyatt, Melbourne, Australia. Earlybird registration closes on 5 November 2007. Abstract submission is also open; the submission deadline is Friday 7 September 2007. If you wish to submit an abstract for an oral or poster presentation please visit the website www.pco.com.au/axaa2008. [Contact: Sarah Mason, Conference Secretariat, Tel: +61 24984 2554; Fax: +61 24984 2755; Email: axaa@pco.com.au].

\section{0-14 March 2008}

International Centre for Diffraction Data, Spring Meeting. Newtown Square, Pennsylvania, USA. [Contact: Linda Shertz, International Centre for Diffraction Data, 12 Campus Boulevard, Newtown Square, PA 19073-3273, USA. Tel: 1 (610) 325 9814; Fax: 1 (610) 325 9823; E-mail: shertz@icdd.com; Info: http://www.icdd.com].

\section{8-10 April 2008}

British Crystallographic Association Annual Spring Meeting. York, England, UK. [Contact: Info: http:// crystallography.org.uk].

\section{May-5 June 2008}

American Crystallographic Association Annual Meeting. Knoxville, Tennessee, USA. Local Chair, Jason Hodges, Program Chairs, Paul Butler and Dean Miles. [Info: http:// www.hwi.buffalo.edu/aca/meetingspg_list/futuremeetings. html].
9-14 June 2008

10th International Conference on Quasicrystals. Zurich, Switzerland. Abstracts are invited in all areas of study, including synthesis, crystal growth and structure, phase stability, surfaces and thin films, physical properties, applications, and new frontiers of quasicrystals and cluster-based complex metallic alloys. [Contact: Conference Secretariat, Mrs. Cornelia Aurelio, Laboratory of Crystallography, ETH Zurich, Wolfgang-Pauli-Strasse 10, CH-8093 Zurich, Switzerland. Tel: 41 (44) 632 3769; Fax: 41 (44) 632 1133; E-mail: aurelio@mat.ethz.ch; Info: http://icq10.ethz.ch].

\section{4-8 August 2008}

57th Annual Denver X-ray Conference. Denver, Colorado, U.S.A. Denver Marriott Tech Center Hotel. Sessions, workshops, exhibits. Provides a unique mixture of sessions on training, education, and applications. Also includes papers containing details about state-of-the-art techniques and future developments in X-ray analysis. For more information contact Denise Flaherty, Tel: 610-325-9814, E-mail: Flaherty@icdd.com 〈mailto:Flaherty@icdd.com>, web: www.dxcicdd.com $\langle$ http://www.dxcicdd.com/〉.

\section{6-8 August 2008}

ICRS-8. Denver, Colorado, U.S.A. The Eighth International Conference on Residual Stresses will be held in conjunction with the 2008 Denver X-ray Conference at the Denver Marriott Tech Center Hotel. The conference provides a forum for scientists, academicians, students, and engineers interested in the prediction, evaluation, control, and application of residual stresses. For more information, visit http:// www.dxcicdd.com/icrs/default.htm $\quad\langle$ http://www.dxcicdd. com/icrs/default.htm $\rangle$.

\section{3-31 August 2008}

21st IUCr General Assembly and International Congress of Crystallography. Osaka, Japan. [Info: http:// www.congre.co.jp/iucr2008].

\section{5-30 July 2009}

American Crystallographic Association Annual Meeting. Toronto, Ontario, Canada. [Info: http://www.amer crystalassn.org/meetingspg_list/futuremeetings.html].

\section{August 2009}

25th European Crystallographic Meeting. Istanbul, Turkey. [Info: http://www.ecanews.org/meetings.htm].

\section{Short Courses \& Workshops}

\section{1-6 September 2007}

Fourth International Workshop on Functional Materials. Gdansk, Poland. Held in Gdansk University of Technology and on the Hel Peninsula. [Info: http://www.fnma07.gda.pl/ ?wh $=$ home].

\section{4-14 September 2007}

10th Oxford School on Neutron Scattering. Oxford, England, UK. Held at Mansfield College in the University of
Oxford. "An ideal introduction to the theory, techniques and applications of neutron scattering to the study of condensed matter." [Info: http://www.oxfordneutronschool.org].

\section{6-7 September 2007}

SMARTER Crystallography Workshop. Aveiro, Portugal, Structure elucidation by combining magnetic resonance, computation modeling, and diffraction. Held at the University of Aveiro. [Info: http://www.primarius.org/smarter]. 